bão mạnh mẽ cho chất lượng cuộc sống và sự ổn định sau xạ phẫu Gamma Knife [5]. Trong nghiên cứu của Nông Văn Dương đánh giá tình trạng đau và chất lượng cuộc sống người bệnh ung thư giai đoạn muộn cũng cho thấy mức độ đau ảnh hưởng đáng kể đên chất lượng cuộc sống của bệnh nhân [7]. Trong nghiên cứu của chúng tôi, chỉ số toàn trạng $\geq 90$ và mức độ đau < 5 có chất lượng cuộc sống tốt hơn đáng kể với sự khác biệt có ý nghĩ̉a thống kê.

\section{KẾT LUÂ̂N}

Chất lượng cuộc sống người bệnh ung thư phổi di căn não cải thiện đáng kể sau điều trị xạ phẫu Gamma Knife. Chỉ số toàn trạng Karnofski và mức độ đau là các yếu tố liên quan đến chất lượng cuộc sống người bệnh.

\section{TÀI LIÊUU THAM KHẢO}

1. J. S. Barnholtz-Sloan, A. E. Sloan, F. G. Davis et al, (2004), Incidence proportions of brain metastases in patients diagnosed (1973 to 2001) in the Metropolitan Detroit Cancer Surveillance System, J Clin Oncol, 22(14), 2865-72.

2. L. J. Schouten, J. Rutten, H. A. Huveneers et al, (2002), Incidence of brain metastases in a cohort of patients with carcinoma of the breast, colon, kidney, and lung and melanoma, Cancer, 94(10), 2698-705.

3. J. P. Sheehan, M. H. Sun, D. Kondziolka et al, (2002), Radiosurgery for non-small cell lung carcinoma metastatic to the brain: long-term outcomes and prognostic factors influencing patient survival time and local tumor control, Neurosurg, 97(6), tr. 1276-81.

4. M. Gerosa, A. Nicolato, R. Foroni et al, (2005) Analysis of long-term outcomes and prognostic factors in patients with non-small cell lung cancer brain metastases treated by gamma knife radiosurgery, J Neurosurg, 102 Suppl, tr. 75-80.

5. S. Bragstad, M. Flatebo, G. K. Natvig et al (2017), Predictors of quality of life and survival following Gamma Knife surgery for lung cancer brain metastases: a prospective study, ] Neurosurg, 129 (1), 71-83.

6. Chen, E., Nguyen, J., Zhang, L. et al, (2012), Quality of life in patients with brain metastases using the EORTC QLQ-BN20 and QLQ-C30, J Radiat Oncol 1, 179-186 https://doi.org/10.1007/s13566-012-0016-0.

7. Nông văn Dương, Bùi Thị Huyên, Trương Thái Sơn và cộng sự, (2018), Đánh giá tình trạng đau và chất lượng cuộc sống ngưới bệnh ung thư giai đoan muốn được chăm sóc giảm nihe tại trung tâm ung bướu Thái Nguyên, Tạp chí Khoà học Điêuu dưỡng, 01 (04), 7 - 13.

\title{
TUÂN THỦ ĐIỀU TRI VÀ CHĂM SÓC TƯ VẤN CHO NGƯỜI BÊ̂NH TĂNG HUYẾT ÁP ĐIỀU TRI TẠI BỆNH VIỆN ĐA KHOA KHU VỰC TİNH AN GIANG
}

\section{TÓM TẮT.}

Nghiên cứu mô tả cắt ngang kết hợp phân tích thực hiện trên 385 bệnh nhân tại Khoa Khám bệnh, Bệnh viện đa khoa khu vực Àn Giang từ tháng 09/2020 đến tháng 12/2020 trên bệnh nhân THA của BVĐK khu vực An Giang. Mục tiêu (1) là Mô tả thực trạng tuân thủ điều trị của người bệnh THA tại Khoa Khám bệnh, Bệnh viện đa khoa khu vực An Giang và một số yếu tố liên quan. (2)Phân tích thực trạng chăm sóc tư vấn cho NB tại BVĐK khu vực An Giang. Số liệu thu thập được là bệnh án nghiên cứu về tuân thủ điểu trị của người bệnh như nữ chiếm cao hơn nam giới (50,6\% so với 49,4\%), Tuổi trung bình: $66,1 \pm 12,2$; thời gian bị bệnh trung bình $7,8 \pm 5,6$ năm. Có kiến thức tuân thủ điều trị chiếm $78,7 \%$ và chưa có kiến

\footnotetext{
${ }^{1}$ Bệnh viện ĐK khu vực An Giang

${ }^{2}$ Trường $\oplus H$ Thăng Long

Chịu trách nhiệm chính: Lê Thị Bình

Email: lethibinh1818@gamail.com

Ngày nhận bài: 13.5.2021

Ngày phản biện khoa học: 2.7.2021

Ngày duyệt bài: 15.7.2021
}

Nguyễn Như Phượng ${ }^{1}$, Lê Thị Bình ${ }^{2}$

tuân thủ điều trị chiếm $21,3 \%$. Có tuân thủ TH trong điêu trị chiếm $62,9 \%$ và chưa tuân thủ $T H$ chiếm $37,1 \%$; về CS chung cho NB: ở múć tốt chiếm $74,3 \%$ và mức chưa tốt chiếm $25,7 \%$; tư vấn mức tốt cho NB chiếm $70,4 \%$ và mức chưa tốt còn $29,6 \%$. Có sự khác biệt rõ rệt và có ý nghĩa thống kê giữa tuổi > 60 tuổi và $<60$ tuổi với tuân thủ điều trị $(p<0,05)$, giữa trình độ học vấn dưới Trung học phổ thông và đại học (p $<0,05)$; giữa NB không ăn mặn và có ăn mặn ít; giữa không ăn chất béo và ăn ít chất béo; có hút thuốc lá và không hút thuốc lá với tuân thủ điều trị $(p<0,05)$; giữa mắc bệnh trên 10 năm và dưới 5 năm với tuân thư điều trị $(p<0,000)$. Giữa kiến thức chưa tốt và NB có kiến thức tốt với tuân thủ điêu trị $(p<0,000)$; giữa NB chăm sóc chưa tốt và NB được chăm sóc tốt với tuân thủ điêu trị $(p<0,000)$; giữa chưa được tư vân tốt và được tư vấn tốt với tuân thủ điêu trị $(p<0,05)$.

Tư khóa: Tuân thủ điều trị, kiến thức, thực hành, chăm sóc, tư vấn cho bệnh nhân

\section{SUMMARY \\ COMPLIANCE IN TREATMENT AND \\ COUNSELING CARE FOR HYPERTENSIVE \\ PATIENTS TREATED AT THE DEPARTMENT}




\section{OF EXAMINATION, AN GIANG GENERAL HOSPITAL}

A cross-sectional descriptive study combined with analysis performed on 385 patients at the Department of Examination, An Giang General Hospital from September 2020 to December 2020 on hypertensive patients of the general hospital, An Giang area. Objective (1) is to describe the status of compliance in treatment of hypertensive patients at the Department of Examination, An Giang General Hospital and some related factors. (2) Analysis of the current situation of consulting care for patients at An Giang Regional General Hospital. The collected data are medical records of patients' adherence to treatment, as female patients accounted for more than men $(50.6 \%$ compared to $49.4 \%$ ). Average age: $66.1 \pm 12.2$; the average duration of illness was $7.8 \pm 5.6$ years. Knowledge of treatment adherence accounted for $78.7 \%$ and no knowledge of treatment adherence accounted for $21.3 \%$. Compliance with practice in treatment accounted for $62.9 \%$ and non-compliance with practice accounted for $37.1 \%$; on general care for patients: at a good level $74.3 \%$ and the bad level accounted for $25.7 \%$; Counseling good level for patients accounted for $70.4 \%$ and bad level was $29.6 \%$. There is a clear and statistically significant difference between age $>60$ years old and $<60$ years old with treatment adherence $(p<0.05)$, between education level below high school and university $(p<$ 0.05); between patients who do not eat salt and eat less salt; between not eating fat and eating less fat; smoker and non-smoker with treatment adherence ( $p$ $<0.05$ ); between more than 10 years of disease and less than 5 years of treatment adherence $(p<0.000)$. Between poor knowledge and patients with good knowledge and treatment adherence $(p<0,000)$; between poorly cared for patients and well cared for patients with treatment adherence $(p<0,000)$; between not being consulted well and being well counseled with treatment adherence $(p<0.05)$

Keywords: Treatment adherence, knowledge, practice, care, counseling for patients

\section{I. ĐẶT VẤN ĐỀ}

Tăng huyết áp là bệnh phổ biến trên thế giới cũng như ở Việt Nam, là một trong những bệnh mạn tính gây ra gánh nặng bệnh tật và tử vong nghiêm trọng nhất trên pham vi toàn cầu. Theo báo cáo của hội Tim Mạch học Việt Nam, tính đến tháng 5 năm 2016 tỷ lệ THA là 47,3\%, trong đó chỉ có 31,3\% THA kiểm soát được [3], đến năm 2015 tỷ lệ này ở mức báo động đỏ với hơn 47,3\% người lớn bị tăng huyết áp [1]. Hiện nay tăng huyết áp (THA) gia tăng trên toàn thế giới và được mệnh danh là "kẻ giết người thầm lặng". Tăng huyết áp liên quan đến $69 \%$ nhồi máu cơ tim lần đầu, $74 \%$ các ca bệnh động mạch vành, $77 \%$ đột quy não lần đâu và $91 \%$ các ca suy tim. Với tính chất của bệnh cần phải theo dõi huyết áp và dùng thuốc hạ áp suốt đời, do đó dễ dàng nhận thấy việc người bệnh phải tuân thủ dùng thuốc là vô cùng cần thiết. Tuy nhiên, nhiều nghiên cứu cho thấy tỷ lệ tuân thủ ở bệnh nhân ngoại trú đáng lo ngại và cần có những can thiệp kịp thời. Có nhiều nguyên nhân làm giảm sự tuân thủ trong sử dụng thuốc trên bệnh nhân tăng huyết áp, nhưng nguyên nhân cơ bản được chỉ ra là người bệnh hoàn toàn thụ đông và chỉ quan tâm khi thấy ảnh hưởng tới sức khỏe bản thân, trong khi đó THA tiến triển thầm lặng[5]. Đây thực sự là một thách thức đối với các bác sỹ và điều dưỡng trực tiếp điều trị, CSNB. Vai trò chăm sóc, tư vấn của điều dưỡng đòi hỏi phải kiên trì giúp NB tuân thủ điều trị bằng cách tư vấn kiến thức, thực hành về tuân thủ điều trị cho NB. Từ thực tế trên đề tài "Tuân thủ điêu trị và chăm sóc tư vấn cho người bênh tăng huyết áp điều trị tại Khoa Khám bệnh, Bểnh viện đa khoa khu vực An Giang" được tiến hành nhằm mục tiêu sau:

1. Mô tả thực trang tuân thủ điều tri của người bênh tăng huyết áp điều trị tại Khoa Khám bệnh, Bệnh viện đa khoa khu vực An Giang và một số yếu tố liên quan.

2. Phân tích thức trạng chăm sóc tư vấn cho người bênh tại Bệnh viện đa khoa khu vực An Giang

\section{II. ĐỐI TƯỢNG VÀ PHƯƠ'NG PHÁP NGHIÊN CỨU}

\section{1. Đối tượng nghiên cứu:}

Tiêu chuân lứa chon: Người bênh được chẩn đoán THA đang điều trị ngoai trú tại Khám Bệnh - Bệnh viện ĐKKV Tỉnh An Giang và có thời gian mắc bệnh $\geq 01$ năm. Thời gian: 9/2020 đến $12 / 2020$

2. Thiết kế nghiên cứu: Nghiên cứu mô tả cắt ngang

3. Cỡ mẫu: 385 bệnh nhân tăng huyết áp tại Khám Bênh - Bênh viên ĐKKV Tỉnh An Giang

4. Biến số NC: Tuổi, giới, nghề nghiệp, nơi ở, trình độ học vấn, Tình trạng kinh tế gia đình, Thời gian mắc bệnh, thói quen ăn mặn, béo, hút thuốc lá, uống rượu bia, kiến thức tuân thủ, thực hành tuân thủ, chăm sóc người bệnh, tư vấn cho người bệnh,...

5. Xử lý số liệu: phân tích, xử lý bằng phần mềm SPSS 20.0 để tính tỷ lệ phần trăm, phân tích đơn biến các yếu tố liên quan đến chưa tuân thủ điều trị, khác biệt có ý nghĩa thống kê khi $p<0,05$.

\section{KẾT QUẢ NGHIÊN CỨU}

\section{1. Đặc điểm chung của đôi tượng nghiên cứu \\ Bảng 1. Phân bố đôî tượng nghiên cứu} theo giới, tuôi

\begin{tabular}{|c|c|c|}
\hline & n (385) & Tỷ lệ (\%) \\
\hline Giới: & 190 & 49,4 \\
\hline
\end{tabular}




\begin{tabular}{|c|c|c|}
\hline Nữ & 195 & 50,6 \\
\hline \multicolumn{3}{|c|}{ Tuối của đối tượng nghiên cứu } \\
\hline$<50$ tuối & 36 & 9,4 \\
\hline $50-60$ tuối & 83 & 21,6 \\
\hline$>60$ tuối & 266 & 69,0 \\
\hline Tuối trung bình & \multicolumn{2}{|c|}{$66,1 \pm 12,2$} \\
\hline \multicolumn{3}{|c|}{ Trình độ học vấn của đối tượng nghiên cứu } \\
\hline Đại học & 31 & 8,1 \\
\hline Dưới đại học & 354 & 91,9 \\
\hline ề nghiệ̂ củ & ong $n$ & ên cứu \\
\hline
\end{tabular}

\begin{tabular}{|c|c|c|}
\hline Nông dân, kinh doanh, hưu & 352 & 91,4 \\
\hline Công chức, viên chức & 33 & 8,6 \\
\hline
\end{tabular}

Thời gian bị bệnh trung bình:7,8 $\pm 5,6$ năm

Nhận xét: Tỷ lệ nữ cao hơn nam. Chiếm tỷ lệ cao nhất ở nhóm tuổi > 60, tiếp đến nhóm tuổi 50 - 60, và tỷ lệ thấp nhất thuộc nhóm tuổi $<50$. Hầu hết là dưới đại học $(91,9 \%)$ và chủ yếu là những người làm nghề nông, buôn bán, cán bộ hưu $(91,4 \%)$.

2. Thực trang tuân thủ điêu trị của người bệnh tăng huyết áp

Bảng 2. Thực trạng tuân thủ điều trị của người bệnh tăng huyết áp

\begin{tabular}{|c|c|c|}
\hline Biến số nghiên cứu & n (385) & Tỷ lệ (\%) \\
\hline \multicolumn{3}{|c|}{ Người bệnh có kiến thức hiểu biết về bệnh tăng huyết áp } \\
\hline Có biết dấu hiệu báo trước khi bị THA & 215 & 55,8 \\
\hline Có KT là bệnh tăng huyết áp có nguy hiểm & 204 & 53,0 \\
\hline Có KT là bệnh tăng HA có thể chữa ổn định & 233 & 60,5 \\
\hline Huyết áp cao có có thể kiếm soát được & 252 & 65,5 \\
\hline \multicolumn{3}{|c|}{ Người bệnh có kiến thức về tuân thủ dùng thuốc } \\
\hline Có hiểu tuân thủ uống thuốc là điều quan trọng nhất để kiểm soát huyết áp & 277 & 71,9 \\
\hline Có hiếu khi bị THA phải sử dụng thuốc liên tục trong nhiều năm & 234 & 60,8 \\
\hline Có hiểu nếu không điều trị tốt THA sẽ gây ra biến chứng nguy hiểm & 245 & 63,6 \\
\hline Có hiếu về chỉ cần uống thuốc điều trị THA & 48 & 12,5 \\
\hline Có hiểu về chỉ cần thay đổi lối sống & 81 & 21,0 \\
\hline Có hiểu cần uống thuốc và thay đổi lối sống & 235 & 61,0 \\
\hline \multicolumn{3}{|c|}{ Người bệnh có kiến thức tuân thủ theo dõi bệnh huyết áp theo tư vấn } \\
\hline Kiểm tra huyết áp thường xuyên & 289 & 75,1 \\
\hline Thay đổi chế độ ăn uống, sinh hoạt giúp kiểm soát HA & 242 & 62,9 \\
\hline Có KT biết tri số xác đinh tăng huyết áp & 234 & 60,8 \\
\hline Có kiến thức tuân thủ tái khám theo hen. & 230 & 59,7 \\
\hline \multicolumn{3}{|c|}{ Đánh giá chung về kiến thức tuân thủ điều trị của NB tăng huyết áp } \\
\hline Có kiến thức tuân thủ & 303 & 78,7 \\
\hline Chưa có kiến thức tuân thủ & 82 & 21,3 \\
\hline \multicolumn{3}{|l|}{ Thực hành tuân thủ điều trị của NB tăng THA } \\
\hline Có quên uống thuốc & 214 & 55,6 \\
\hline Có thỉnh thoảng quên thuốc trong 2 tuần & 206 & 53,5 \\
\hline Tự ý mua thuốc mà không báo bác sĩ. & 242 & 62,9 \\
\hline Khi đi du lịch, đi chđi, có đôi lúc quên mang theo thuốc & 199 & 51,7 \\
\hline Có quên uống thuốc ngày hôm qua & 171 & 44,4 \\
\hline Có tự ý dừng thuốc khi thấy sức khỏe tốt. & 215 & 55,8 \\
\hline Có thấy bất tiện khi phải uống thuốc mô̂i ngày không. & 226 & 58,7 \\
\hline Có thường xuyên thấy khó khăn khi phải nhớ uống tất cả thuốc & 181 & 47,0 \\
\hline \multicolumn{3}{|c|}{ Đánh giá chung về thực hành tuân thủ điêu trị của người bệnh } \\
\hline Tuân thủ thực hành & 242 & 62,9 \\
\hline Chưa tuân thủ thực hành & 143 & 37,1 \\
\hline
\end{tabular}

NB có kiến thức về bệnh: hiểu biết về dấu hiệu báo trước khi bị THA $(55,8 \%)$; có hiểu biết bệnh THA có nguy hiểm (53\%); biết về THA có thể chữa ổn định $(60,5 \%)$; biết về bệnh HA có thể kiểm soát được $(65,5 \%)$.

NB có kiến thức tuân thủ dùng thuốc điều trị tăng huyết áp: có kiến thức về uống thuốc là điều quan trọng nhất để kiểm soát huyết áp chiếm 71,9\%; Hiểu khi bị THA phải sử dụng thuốc liên tục nhiều năm chiếm 60,8\%; biết không điều trị tốt THA sẽ gây ra biến chứng nguy hiểm chiếm $63,6 \%$; Hiểu là chỉ cần uống thuốc điều trị THA chiếm 12,5\%; Hiểu là chỉ cần thay đổi lối sống chiếm $21 \%$; Hiểu là chỉ cần 
uống thuốc và thay đổi lối sống chiếm $61 \%$

Có kiến thức tuân thủ theo dõi bệnh huyết áp theo tư vấn: Có kiến thức tuân thủ kiểm tra huyết áp thường xuyên chiếm $75,1 \%$; Có kiến thức tuân thủ về Thay đổi chế độ ăn uống, sinh hoạt giúp kiểm soát HA chiếm $62,9 \%$; Có kiến thức hiểu biết trị số xác định tăng huyết áp chiếm $60,8 \%$; Có kiến thức tuân thủ tái khám theo hẹn chiếm $59,7 \%$.

Đánh giá chung vê kiến thức tuân thủ điêu trị: Có kiến thức tuân thủ $(78,7 \%)$, không $(21,3 \%)$
Thực hành tuân thủ về sử dụng thuốc điêu trị: không quên (44,4\%); Trong 2 tuần qua có ngày không quên thuốc (46,5\%); Không tự ý mua thuốc $(37,1 \%)$; Khi đi du lịch, đi chơi, có đôi lúc không quên $(48,3 \%)$; thuốc ngày hôm qua không quyên $(55,6 \%)$; tự ý dừng thuốc khi thấy sức khỏe tốt $(44,2 \%)$; thâyy bất tiện khi phải uống thuốc mỗi ngày $(41,3 \%)$; Không thấy khó khăn khi phải nhớ uống tất cả thuốc (53\%).

Đánh giá chung về thực hành tuân thủ điêu trị: có tuân thủ thực hành là $62,9 \%$ và chưa tuẩn thủ thực hành chiếm $37,1 \%$.

4. Một số yếu tố liên quan đến tuân thủ điêu trị

4.1. Liên quan giữa đặc điểm chung của đối tượng nghiên cứu với tuân thủ điều trị

Bảng 4. Sự liên quan giữa đặc điểm của đối tượng nghiên cứu với tuân thủ điều trị

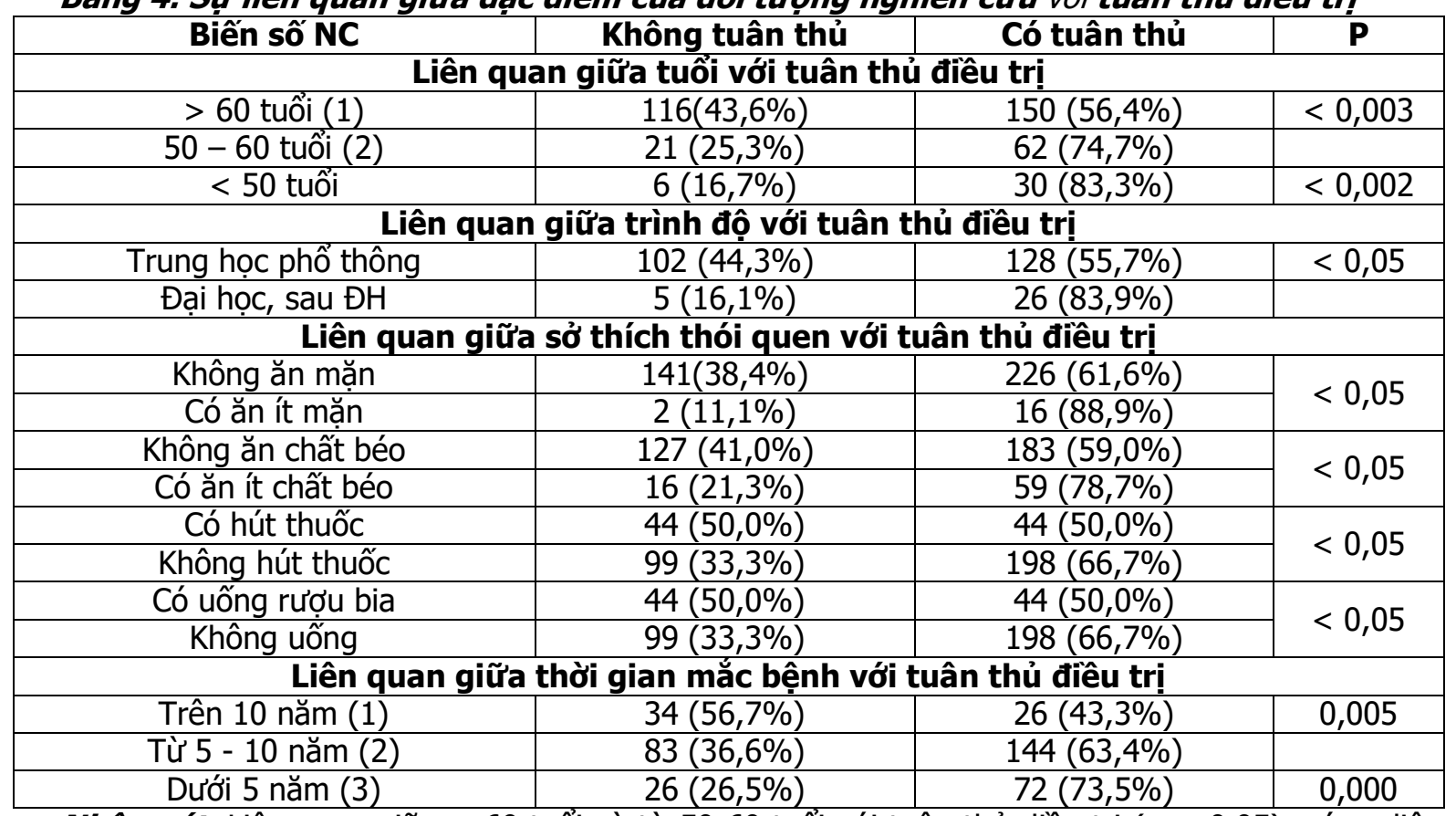

Nhận xét: Liên quan giữa $>60$ tuối và từ $50-60$ tuối với tuân thủ điều trị $(p<0,05)$; có sự liên quan giữa $>60$ tuổi và $<50$ tuổi với tuân thủ điều trị $(p<0,05)$. Liên quan giữa $<$ TH phổ thông và đại học, SĐH với tuân thủ điêuu trị $(p<0,05)$. Có sự khác biệt giữa NB không ăn mặn và có ăn mặn ít; giữa NB không ăn chất béo và ăn ít chất béo; giữa NB có hút thuốc lá và không hút thuốc lá; giữa NB có uống nhiều rượu bia và không uống rượu bia với tuân thủ điều trị $(p<0,05)$. Liên quan giữa NB có thời gian mắc bệnh $>10$ năm và thời gian mắc từ $5-10$ năm với tuân thủ điều trị $(p<0,005)$; giữa có thời gian mắc bệnh $>10$ năm và $<5$ năm với tuân thủ điều trị $(p<0,000)$.

Bảng 5. Liên quan giữa kiến thức, thực hành với tuân thủ điều trị

\begin{tabular}{|c|c|c|c|}
\hline \\
\hline Biến số NC & Không tuân thủ & Có tuân thủ & $\mathbf{P}$ \\
\hline \multicolumn{4}{|c|}{ Liên quan giữa kiên thức chung vê bệnh THA với tuân thủ điêu trị } \\
\hline Kiến thức chưa tốt & $44(53,7 \%)$ & $38(46,3 \%)$ & $<0,000$ \\
\hline Kiến thức tốt & $99(32,7 \%)$ & $204(67,3 \%)$ & \\
\hline \multicolumn{4}{|c|}{ Liên quan giữa thực hành chung với tuân thủ điều trị } \\
\hline Chưa tốt & $102(43,8 \%)$ & $131(56,2 \%)$ & $<0,001$ \\
\hline Tốt & $41(27,0 \%)$ & $111(73,0 \%)$ & \\
\hline
\end{tabular}

Nhận xét: có sự liên quan rõ rệt giữa kiến thức chưa tốt và NB có kiến thức tốt về bệnh THA vớl tuân thủ điều trị $(p<0,000)$. Có sự liên quan rõ rệt giữa thực hành chưa tốt và có thực hành tốt với 
tuân thủ điều trị $(p<0,001)$

Bảng 6. Liền quan giữa hoạt động chăm sóc, tư vấn với tuân thủ điều trị

\begin{tabular}{|c|c|c|c|}
\hline Biến số NC & Không tuân thủ & Có tuân thủ & $\mathbf{P}$ \\
\hline \multicolumn{4}{|c|}{ Liên quan giữa hoạt động chăm sóc với tuân thủ điều trị } \\
\hline Chăm sóc chưa tốt & $55(55,6 \%)$ & $44(44,4 \%)$ & \multirow{2}{*}{0,000} \\
\hline Chăm sóc tốt & $88(30,8 \%)$ & $198(69,2 \%)$ & \\
\hline \multicolumn{4}{|c|}{ Liên quan giữa hoạt động tư vẫn, GDSK với tuân thủ điều trị } \\
\hline Tư vấn chưa tốt & $54(47,4 \%)$ & $60(52,6 \%)$ & 0,007 \\
\hline Tư vấn tốt & $89(32,8 \%)$ & $182(67,2 \%)$ & \\
\hline
\end{tabular}

Nhân xét: có liên quan rõ rệt giữa CS chưa tốt và NB được CS tốt với tuân thủ điều trị $(\mathrm{p}<$ $0,05)$. Liên quan giữa NB chưa được tư vấn, tốt và NB được tư vấn tốt với tuân thủ điều trị $(p<0,05)$

\section{BÀN LUÂ̂N}

1. Đặc điểm của đối tượng nghiên cứu: nữ chiếm cao hơn nam giới $(50,6 \%$ so với $49,4 \%$ ) và kết quả này cũng tương dồng với KQNC của Đố Thị Hiến năm 2020 [3] cũng có tỷ lệ nữ chiếm cao hơn nam giới $(55,5 \%$ so với $44,5 \%)$, tương đồng với Nguyễn Hồng Minh và CS có nữ $55 \%$ và nam $45 \%$ [4]. Về tuổi: tỷ lệ cao nhất là nhóm tuổi trên 60 chiếm $69 \%$, kết quả của chúng tôi chỉ thấp hơn của Phạm Thị Hồng Vân [8] có người bệnh > 60 tuổi chiếm $65 \%$; tiếp đến nhóm tuổi $50-60$; và tỷ lệ thấp nhất thuộc nhóm tuổi < 50 là nhóm tuổi lao động, làm làm việc trong nhiều môi trường khác nhau. Hầu hết là dưới đại học chiếm $91,9 \%$ cao hơn KQNC của Đỗ Thị Hiến là 69,75 [3] và chủ yếu là những người làm nghề nông, buôn bán hưu $(91,4 \%)$. Về nghề nghiệp: chiếm tỷ lệ cao nhất gộp cả 3 đối tượng là Nông dân, kinh doanh, hưu trí $(91,4 \%)$, KQNC này cao hơn với KQNC của Đỗ thị Hiến gộp cả nông dân $(8,5 \%)$, kinh doanh $(15,25 \%)$, hưu trí $(50,5 \%)$ chỉ là $74,25 \%$. Tiếp theo là đối tượng công chức, viên chức thì trong NC của chúng tôi chỉ chiếm $8,6 \%$ cũng thấp hơn $\mathrm{KQ}$ của Đỗ Thị Hiến $(8,6 \%$ so với $17,75 \%)[3]$. NB có kiến thức về bệnh: hiểu biết về dấu hiệu báo trước khi bị THA chiếm $55,8 \%$; có hiểu biết bệnh THA có nguy hiểm chiếm 53; biết về THA có thể chữa ổn định chiếm $60,5 \%$; biết về bệnh $\mathrm{HA}$ có thể kiểm soát được chiếm $65,5 \%$. NB có kiến thức hiểu biết về bệnh THA chiếm $72,7 \%$ [2]

2. Kiến thức tuân thủ điêu trị của NB tăng huyết áp:

- Kiến thức tuân thủ dùng thuốc của NB tăng huyết áp: NB có kiến thức về uống thuốc là điều quan trọng nhất để kiểm soát huyết áp chiếm $71,9 \%$. Kết quả này cũng tương đồng với Đỗ Thị Hiến năm 2020 tại bệnh viện 108[3]. NB có kiến thức: khi bị THA phải sử dụng thuốc liên tục trong nhiều năm chiếm $60,8 \%$. NB có kiến thức: về không điều trị tốt THA sẽ gây ra biến chứng nguy hiểm chiếm $63,6 \%$. Kết quả của chúng tôi cho thấy NB có kiến thức là chỉ cần uống thuốc và thay đổi lối sống chiếm $61 \%$ tỷ lệ này thấp hơn của Đỗ Thị Hiến $(72,5 \%)$ [3].

Kiến thức tuân thư theo dõi bệnh huyết áp theo tư vấn: NC của chúng tôi, $75,1 \%$ có kiến thức tuân thủ kiểm tra huyết áp thường xuyên chiếm cao hơn của Đỗ Thị Hiến là $71,75 \%$ [3] Kết quả này của chúng tôi cũng cao hơn so với nghiên cứu của Ngô Thị Hương Giang (2013) [1] tỷ lệ đối tượng nghiên cứu trả lời đúng về thời gian SD thuốc hạ áp là là $67,9 \%$. Kiến thức về điều chỉnh lối sống: cho thấy, phần lớn NB đều có kiến thức tuân thủ về thay đổi chế độ ăn uống, sinh hoạt kiểm soát HA chiếm $62,9 \%$, tỷ lệ này cao hơn kết quả nghiên cứu của Phạm Thị Hồng Vân là 37,2\%[8]. Có kiến thức tuân thủ tái khám theo hẹn chiếm $59,7 \%$ thấp hơn nhiều so với $\mathrm{Ngô}$ Vương Hoàng Giang [2] có tỷ lệ tái khám chiếm $98,6 \%$. NC của chúng tôi NB không có kiến thức tuân thủ việc TDSK định kỳ là 40,3\%, cao hơn gấp 4 lần so với Đỗ Thị Hiến là 9,25\%[3].

Đánh giá chung về kiến thức tuân thủ điêu trị: Có kiến thức tuân thủ $(78,7 \%)$ và không (21,3\%). Kết quả này của chúng tôi cao hơn của Đỗ Thị Hiến cũng có đánh giá kiến thức chung về điều trị bệnh tăng huyết áp có mức đat thấp hơn 1,6 lần so với kết quả của chúng tôi $(72,7$ so với $45,5 \%)$ và ngược lại ở mức chưa đạt so với Đỗ Thị Hiến (21,3\% so với 54,5\%) [3]

\section{Về thực hành tuân thủ điêuu trị:}

- Thực hành tuân thủ về sử dụng thuốc điêu trị: không quên (44,4\%); Trong 2 tuần qua có ngày không quên thuốc (46,5\%); Không tự ý mua thuốc $(37,1 \%)$; Khi đi du lịch, đi chơi, có đôi lúc không quên chiếm $48,3 \%$; thuốc ngày hôm qua không quyên (55,6\%); tự ý dừng thuốc khi thấy sức khỏe tốt $(44,2 \%)$; thây bất tiện khi phải uống thuốc mỗi ngày $(41,3 \%)$; không thấy khó khăn khi phải nhớ uống tất cả thuốc (53\%). Việc thức hành tuân thủ về sử dung thuốc điều trị đa phần có KQ cao hơn của Đố Thị Hiến năm 2020, 
nhưng lại thấp hơn NC của Trần Thị Thùy Nhi [5]

- Đánh giá chung về thực hành tuân thủ điêu trị: có tuân thủ thực hành chung là $62,9 \%$ và chưa tuân thủ thực hành chiếm $37,1 \%$. $K Q$ này cao hơn của Trần Thị Thùy Nhi [5] khi tư vấn lần đầu không tuân thủ chiếm $36,6 \%$ và sau 3 tháng tỷ lệ đã giảm còn $26,3 \%$. Nhưng kết quả tuân thủ dùng thuốc của chúng tôi lại thấp hơn rất nhiều so với của Phạm Thị Hồng Vân năm 2020 có KQ tuân thủ thực hành chiếm khá cao tới $96,1 \%$; chưa tuân thủ thực hành chỉ chiếm 3,9\%[8].

4. Một số yếu tố liên quan đến tuân thủ điêuu trị của NB tăng HA

4.1. Liên quan giữa đặc điểm chung của đối tượng nghiên cứu với tuân thủ điêu trị

Về tuối: Có sự liên quan giữa $>60$ tuổi và từ 50-60 tuổi với tuân thủ điều trị $(p<0,05)$; có sự liên quan giữa $>60$ tuổi và $<50$ tuổi với tuân thủ điều trị $(p<0,05)$. Kết quả NC của chúng tôi cũng phù hợp với kết quả nghiên của Đỗ Thị Hiến năm 2020 [3] và của Phạm Thị Hồng Vân năm 2020 cũng có sự khác biệt và có ý nghĩa thống kê $(p<0,05)[8]$.

Về trinh độ hoc vấn: Có sự liên quan giữa dưới trung học phổ thông và đại học, $\mathrm{S} Đ H$ với tuân thủ điều trị $(p<0,05)$. Kết quả của chúng tôi cũng tương đồng với Đố Thị Hiến bệnh nhân có trình độ từ đại học trở lên có mức tuân thủ cao hơn so với nhóm dưới đại học [3].

Về sở thích, lối sống: Có liển quan giữa NB không ăn mặn và có ăn mặn ít; giữa NB không ăn chất béo và ăn ít chất béo; giữa NB có hút thuốc lá và không hút thuốc lá; giữa NB có uống nhiêu rượu bia và không uống rượu bia với tuân thủ điều trị $(p<0,05)$. Tuy nhiên, KQNC của chúng tôi lại trái ngược với KQ của Đố Thị Hiến là chưa tìm thấy sự khác biệt này, có lẽ do cõ mẫu nhỏ.

Về thời gian mắc bênh: Có sự liên quan giữa $N B$ có thời gian mắc bệnh $>10$ năm và thời gian mắc từ 5-10 năm với tuân thủ điều trị $(p<0,005)$. KQ này lại trái ngược với Phạm Thị Hồng Vân là chưa tìm thấy liên quan giữa NB có thời gian bị bệnh THA với tuân thủ điều trị $(p>0,05)[8]$.

Liên quan giữa kiến thức, thực hành với tuân thủ điêuu trị: Có sự liên quan rõ rệt giữa kiến thức chưa tốt và NB có kiến thức tốt về bệnh THA với tuân thủ điều trị $(p<0,000)$. Kết quả này cũng tương đồng với kết quả của Đố Thị Hiến cũng có kiến thức chung tuân thủ điều trị bệnh tăng huyết áp có sự khác biệt có ý nghĩa thống kê giữa 2 nhóm NB tăng $\mathrm{HA}$ "có tuân thủ điều trị" và "không tuân thủ điều trị" với $\mathrm{p}<$ 0,05 [3]. KQNC của chung tôi cho thấy, có sự khác biệt giữa thực hành chưa tốt và NB tăng huyết áp có thực hành tốt với tuân thủ điêu trị ( $\mathrm{p}$ $<0,001)$. Kết quả của chúng tôi cũng tương đồng với Đố Thị Hiến [3].

Liên quan giữa hoạt động chăm sóc, tư vấn với tuân thủ điều trị: Bảng 6 cho thấy, có sự liên quan rõ rệt giữa chăm sóc chưa tốt và NB được chăm sóc tốt với tuân thủ điều trị $(p<$ $0,000)$ có thể giải thích rằng khi NB đến khám và điêu trị ngay từ đầu đã được điêuu dưỡng giao tiếp rất tận tình được NB hài lòng tới 97,7\% [7], theo Bùi Minh Thông nhu câu cân được chăm sóc của NB chiếm $91,4 \%$, cần được tư vấn sức khỏe rất lớn chiếm tới 80,9\%[6]. Có sự liên quan giữa NB chưa được tư vấn, tốt và NB được tư vấn tốt với tuân thủ điều trị $(p<0,007)$.

\section{KẾT LUẦN}

1. Thực trạng tuân thủ điều trị của người bệnh tăng huyết áp: Có kiến thức tuân thủ $(78,7 \%)$ và chưa tuân thủ $(21,3 \%)$. Có tuân thủ thực hành $(62,9 \%)$ và chưa tuân thủ thực hành $(37,1 \%)$.

2. Thực trạng chăm sóc cho NB tăng HA: ở mức tốt chiếm $74,3 \%$ và mức chưa tốt chiếm $25,7 \%$

3. Thực trạng tư vấn cho NB tăng $\mathrm{HA}$ : mức tốt chiếm $70,4 \%$ và mức chưa tốt còn $29,6 \%$

\section{TÀI LIẸU THAM KHẢO}

1. Ngô Thị Hương Giang (2013), Kiến thức, thực hành và một số yếu tố liên quan đến phòng biến chứng ở người bi tăng huyết áp tai huyên Thanh Trì, Thành phố Hà Nội, 2013, Luận văn thạc sỹ Y tế công cộng, Trường Đai học $Y$ tế Công Cộng.

2. Ngô Vương Hoàng Giang (2020) Thực trang tuần thủ điều trị của bệnh nhân tăng huyết áp điều tyrij ngoaii trú taai Khoa Khám bệnh, Trung tâm Y tế Huyện Thoại Sơn, tỉnh An Giang năm 2020, Tạp chí Ý học thực hành, Tập 31, số 62021

3. Đố Thị Hiến và CS (2020), Đánh giá sự tuân thủ điêu trị ở bệnh nhân tang huyết áp được điều tri ngoại trú tại Phòng khám Nôi Tim mạch - Bênh viện Trung ưởng Quân đội 108, Tạp chí Y Dược lâm sàng 108, Hội nghị khoa học điều dưỡng bệnh viện 2020, tập 15, 11/2020,

4. Nguyến Hồng Minh và CS (2018), Mô tả nhu cầu của ngưới bệnh đến kham tại Khoa Khám bênh, bệnh viện Trung ương Quân đội 108, quý 1 nằm 2018. Tap chí Y Dước lâm sàng i08, Hôi nghi khoa học điều dưỡng 2018, tập 13, số đặc biệt $8 / 2018$, trang $300-307$.

5. Trân Thị Thùy Nhi và CS (2017), Nghiên cứu tuân thư sử dụng thuốc theo thang điêm Mirisky (VMAS - 8) và hiêu quả tư vấn trên bênh nhân đái tháo đường típ 2. Hội Nội tiết và Đái tháo đường miên trung, 17/3/2021. Chuyên đê, đái tháo đường, tap chí số $46+47$

6. Bùi Minh Thông và CS (2018), Thực trang công tác giáo duc sức khỏe cho người bệnh tại bênh viện Nội tiết trung ương năm 2018. . Kỷ yếu Hội nghị khou học bệnh viện Nội Tiết trung ương mở rộng năm 2019. Trr 349 - 355. 
7. Trân Thị Thanh Thảo, Đào Thi Thu Giang (2020), Thực trang kỹ năng giáo tiếp, ứng xử với bênh nhân của điều dưỡng Khoa Khám bềnh Cán bộ cao cấp, Bệnh viện Trung ương Quân đội 108 nẳm 2020. Tạp chí Ý Dược lấm sàng 108, tập 15, số đặc biệt 11/2020,
8. Phạm Thị Hông Vân và CS (2020), Tìm hiểu kiến thức và thức hành tuân thư điều trị của bệnh nhân tăng huyết áp tai Viện Điêu trị Cán bộ cao cấp Quân đội. Tap chí Y Dược lâm sàng 108, Hội nghị khoa học điêu dương bệnh viện 2020, tập 15 , số đặc biệt $11 / 2020$

\section{NGHIÊN CỨU ĐĂC ĐIỂM LÂM SÀNG VÀ CÂN LÂM SÀNG CỦA BÊ̂NH NHẦN VIÊM PHỔI MẮC PHẢI CộNG ĐỒNG TẠI BỆNH VIÊ̂N HỮU NGHI! ĐA KHOA NGHỆ AN}

\begin{abstract}
TÓM TẮT
Mục tiêu: Nghiên cứu một số đặc điểm lâm sàng, cân lâm sàng của bệnh nhân viêm phổi mắc phải cộng đồng điều trị tại Bệnh viện hữu nghị đa khoa tỉnh Nghệ An. Phương pháp: Nghiên cứu mô tả cắt ngang được thực trên 80 bệnh nhân viêm phổi mắc phải cộng đồng điều trị tại Bệnh viện hữu nghị đa khoa tỉnh Nghệ An từ tháng 01/2021 đến tháng $04 / 2021$. Kết quả: $81,2 \%$ có độ tuổi $\geq 65$ tuổi, $57,5 \%$ là nam giới và $42,5 \%$ là nữ giới; $48,8 \%$ có hút thuốc và $38,8 \%$ có lạm dụng rượu; Bệnh kèm theo: $31,3 \%$ có suy tim, 5,0\% có di chứng tai biến mạch máu não, $13,8 \%$ có đái tháo đường và $31,3 \%$ có bểnh lý phổi man tính; Mức độ bệnh theo thang điểm CURB65: 13,8\% mức độ nhẹ, 58,7\% mức độ trung bình và $27,5 \%$ mức độ năng; Rối loan ý thức, thở nhanh và tổn thương lan tỏa trên phim x-quang phổi là các dấu hiệu liên quan đến mức đô năng của bệnh. Kết luận: Nghiên cứu cho thấy đa sổ bểnh nhân viêm phổi mắc phải cồng đồng có đồ tuổi trên 65 tuổi $(81,2 \%)$, các dấu hiệu khó thở, rối loạn ý thức và tổn thương lan tỏa trên phim $x$-quang là các dấu hiệu liên quan đến mức độ nặng của bệnh.

Tứ khóa: Lâm sàng, cận lâm sàng, viêm phổi mắc
\end{abstract} phải cộng đồng

\section{SUMMARY \\ RESEARCH ON CLINICAL AND SUBCLINICAL FEATURES OF PATIENTS WITH COMMUNITY- ACQUIRED PNEUMONIA PATIENTS AT NGHE AN FRIENDSHIP GENERAL HOSPITAL}

Objectives: To study some clinical and subclinical features of patients with community-acquired pneumonia who were treated at Nghe An Friendship General Hospital. Methods: A cross-sectional descriptive study was performed on 80 patients with community-acquired pneumonia who were treated at Nghe An Friendship General Hospital from January 2021 to April 2021. Results: $81.2 \%$ were $\geq 65$ years

${ }^{1}$ Dại họ Y khoa Vinh

Chịu trách nhiệm chính: Nguyễn Văn Tuấn

Email: tuanminh1975@gmail.com

Ngày nhận bài: 12.5 .2021

Ngày phản biện khoa học: 6.7.2021

Ngày duyệt bài: 16.7.2021

\section{Nguyễn Văn Tuấn ${ }^{1}$, Trần Thị Kiều Anh ${ }^{1}$}

old, $57.5 \%$ were male and $42.5 \%$ were female; smoking (48.8\%) and alcohol abuse (38.8\%); Comorbidities: $31.3 \%$ had heart failure, $5 \%$ had sequelae of stroke, $13.8 \%$ had diabetes and $31.3 \%$ had chronic lung disease; The severity of disease according to the CURB65 scale: mild (13.8\%), moderate $(58.7 \%)$ and severe $(27.5 \%)$; Impaired consciousness, tachypnea and diffuse lesions on chest $x$-ray are signs that related to the severity of the disease. Conclusion: The study showed that the majority of patients with community-acquired pneumonia were over 65 years old $(81.2 \%)$, signs of dyspnea, impaired consciousness and diffuse lesions on chest x-ray were signs that related to the severity of the disease.

Keywords: Clinical, subclinical, communityacquired pneumonia

\section{I. ĐẶT VẤN ĐỀ}

Viêm phổi mắc phải cộng đồng (VPMPCĐ) là một bệnh phổ biến ảnh hưởng đến khoảng 450 triệu người mỗi năm và xảy ra ở tất cả các nơi trên thế giới. Theo Tổ chức y tế Thế giới (WHO), VPMPCĐ là nguyên nhân gây tử vong đứng hàng thứ 6 trong các bệnh và đứng đầu trong các bênh nhiễm khuẩn [6]. Ở Viêt Nam, VPMPCĐ là một bệnh lý nhiễm khuẩn thường gặp nhất trong các bệnh nhiễm khuẩn trên thực hành lâm sàng, chiếm 12\% các bênh phổi. Năm 2014, tỷ lê mắc viêm phổi ở nước ta là 561/100.000 người dân, đứng hàng thứ hai sau tăng huyết áp, tỷ lệ tử vong do viêm phổi là 1,32/100.000 người dân, đứng hàng đâu trong các nguyên nhân gây tử vong [1].

Các hướng dẫn quản lý điều trị dựa vào hiểu biết về biểu hiện lâm sàng, cận lâm sàng của bênh và đặc điểm dịch tễ học của bệnh tại địa phương. Bệnh viện hữu nghị đa khoa Nghệ An hàng năm tiếp nhận điêuu trị, chăm sóc gân 4000 bệnh nhân bị bệnh đường hô hấp trong đó VPMPCĐ chiếm 10 - 15\%. Đa số các bênh nhân VPMPCĐ đã được điều trị từ tuyến huyện, một số khác đã điêu trị tại nhà trước đó nên tính chất bệnh đã thay đổi và quá trình xét nghiệm xác định căn nguyên của bệnh cũng gặp nhiều khó 